\title{
The Evolutionary Reorganization of Ontogeny and Origin of Multicellularity
}

\author{
I. V. Dovgal \\ Schmalhausen Institute of Zoology, Ukrainian National Academy of Sciences, B. Khmelnitskogo ul. 15, Kiev, 01601 Ukraine \\ e-mail:dovgal@izan.kiev.ua \\ Received June 16, 2009
}

\begin{abstract}
The formation of morphogenetic mechanisms during emergence of multicellularity is discussed in this article.

DOI: $10.1134 / \mathrm{S} 1062359010020056$
\end{abstract}

For members from various groups of eukaryotes, some hypotheses on the probable ways of transition to multicellularity were suggested. Thus, there are some alternative ideas considered by Ivanov in 1968 with regard to the origin of multicellular animals (Metazoa). The existing hypotheses can be divided to three groups: (1) complete or incomplete division in the common extracellular matrix creating colonies; (2) cellularization of the multinucleus (poly-energy) cell and (3) aggregation of cells, caused by chemical stimulus.

Among the latter suggestions, it is widely that ancestors of Metazoa were colonial flagellates (Gaidos et al., 2007) and sponges, having choanocytes which are close in structure to choanoflagellates, the supposed ancestors of multicellular animals (Dondua, 2005a; Frolov, 2006). This hypothesis was also supported by the philogenetic trees built on the basis of DNA sequencing where choanoflagellates were placed in the same cluster as Metazoa.

According to an alternative version (Maldonado, 2004), choanoflagellates are secondary simplified sponges and fungi were the ancestors of multicellular animals (Müller, 2003).

At the same time, Seravin and Goodkov (2005) supposed that the presence of amoeboid properties in the cell among Metazoa at early stages of morphogenesis testifies that some ameboflagellates were the ancestors of Metazoa and multicellular organisms formed only by this way (due to cell aggregation but not due to differentiation of the cell colonies).

The aim of this article is to discuss how the mechanisms of ontogenesis regulation could change during the transition from the unicellular to multicellular organization level.

On our opinion, the search for continuity between ontogenesis regulation mechanisms of protozoa and early ontogenesis mechanisms of multicellular animals is more promising (Dovgal, 2002a,b; Dovgal, 2007, 2008, and 2009).
Sewertzoff affirmed in 1939 that there is no ontogenesis in unicellular organisms and they are present only in Volvox in the most primitive form. Particularly, in the opinion of Sewertzoff (1934), the parent cell of protozoa as a result of division provides the daughter cells but not the embryo, which further develops. According to Sewertzoff's suggested scheme of evolution of Metazoa ontogenesis (Fig. 1), the ontogenesis begins only in colonial protists (for instance the formation of Volvox colonies with individuals morphologically and functionally differentiated). The origin of morphogenetic mechanisms of multicellular organisms is still not clear.

Most embryologists after Sewertzoff denied the presence of individual development on the cell level of organization. For instance, Dondua (2005b) claimed that only the first multicellular animals could have mechanisms that provide differential gene activity and various morphogenetic processes. However, the article does not make it clear how morphogenetic mechanisms were created in the first multicellular animals. Ivanov (1968) most likely supposed that Sewertzoff's idea is speculative. In our opinion it would be normal to find the mechanisms of eukaryotes on the cellular organizational level.

The phrase "cell ontogenesis" was first used by Bauer (1935). Tokin, a disciple of Bauer (1934), drew attention to every individual (tomit) created as a result of hypotrich division, which receives a different set of cirri (cilliary bundles) and, respectively, must resfore the missing bundles. Tokin interpreted this process as ontogenesis and consecutive steps of creating of new cilliary apparatus were considered as recapitulations.

The works of Bauer and Tokin did not receive enough attention, and these ideas were returned to only in the 1950s-1970s. The processes that occur particularly in infusoria in various forms of asexual reproduction were considered as part of ontogenesis (Dogiel, 1951; Foissner, 1996). 


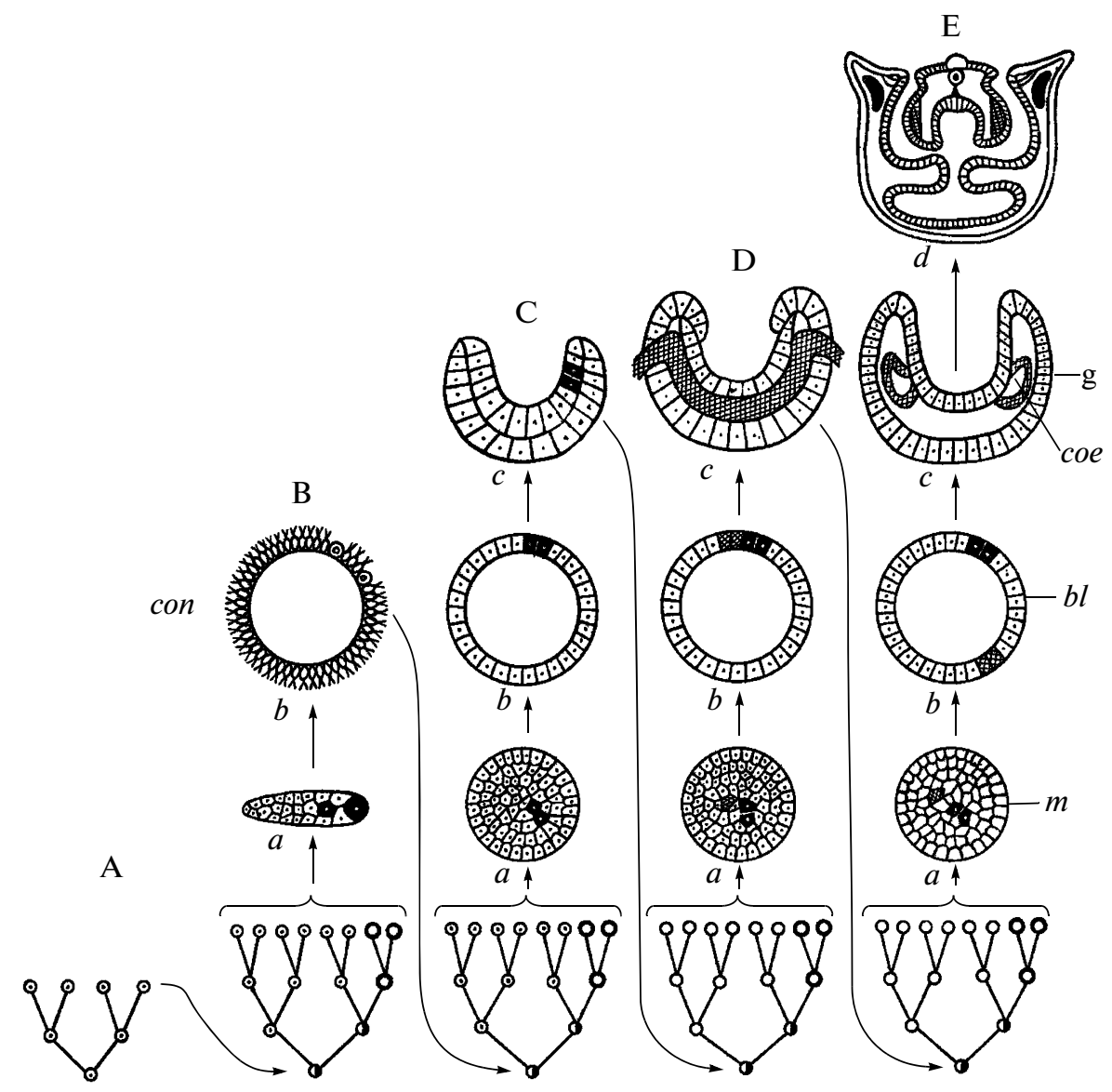

Fig. 1. Hypothetical phase of ontogenesis evolution in bilateral Metazoa, according to A.N. Sewertzoff (Ivanov, 1968). A-reproduction of free-living unicellular animals, the daughter cells become separate after each division; B-ontogenesis of the unicellular colony (Volvox type), parent cell undergoes multiple division, but daughter cells create a colony; C-ontogenesis of simple Metazoa (Hydra type); D - evolution of ontogenesis of primary bilateral animal with developed mesoderm by archallaxis; E-ontogenesis of the high bilateral animal with prolonged embryonic development due to additional extensions. The gametes marked with black color and mesoderm shaded in gray. $a-d$, Subsequent stages of ontogenesis, $b l$ - blastula, coe - coelom, con-protozoa colony, $g$ - gastraea, $m$ - morula.

In contrast to many other protists, the cell body of infusoria has external structures located asymmetrically that are visible in a light microscope. First of all this regards the cell mouth, i.e., the cytostome. The ciliates are characterized by transverse fission which results in one of the daughter cells obtaining the cytostome (and the appropriate cilliary apparatus) from the parent cell and the other cell must construct it (Fig. 2). As was found, the construction of the new mouth apparatus (stomatogenesis) occurs in various groups of infusoria in different ways. The order of processes that occur during stomatogenesis of infusoria is interpreted as ontogenesis. Accordingly, different types of stomatogenesis characterize various classes of infusoria. Additionally, the steps of stomatogenesis are considering as recapitulations.

Before the wide application of molecular techniques, stomatogenesis was almost the sole source of information for phylogenetic reconstructions within the Ciliophora phylum. However, using the molecu- lar-genetic methods did not change its importance for phylogenetic and systematic understanding of infusoria, because the schemes of phylogenetic relations of taxa of infusoria on the class and order level, which are obtained taking into account the type of stomatogenesis and according to the data of DNA sequencing, corresponding well to each other (Foissner, 1996).

Jankowski (1972) considered any changes (reconstructions) of the ciliary apparatus of infusoria (and not only the mouth) after asexual reproduction as ontogenetical.

Eigner reconstructed the phylogeny of some groups of hypotrichs using analysis of ontogenesis of these ciliates on a new methodological level independently from Tokin's studies (Eigner, 1997).

In this case we (Dovgal, 2002a, b) considered the processes of stomatogenesis and reconstruction of the tentaculate apparatus of predatory sessile infusoriasuctoria during their budding and metamorphosis of settlement stages, i.e., telotrochs (Fig. 2). 


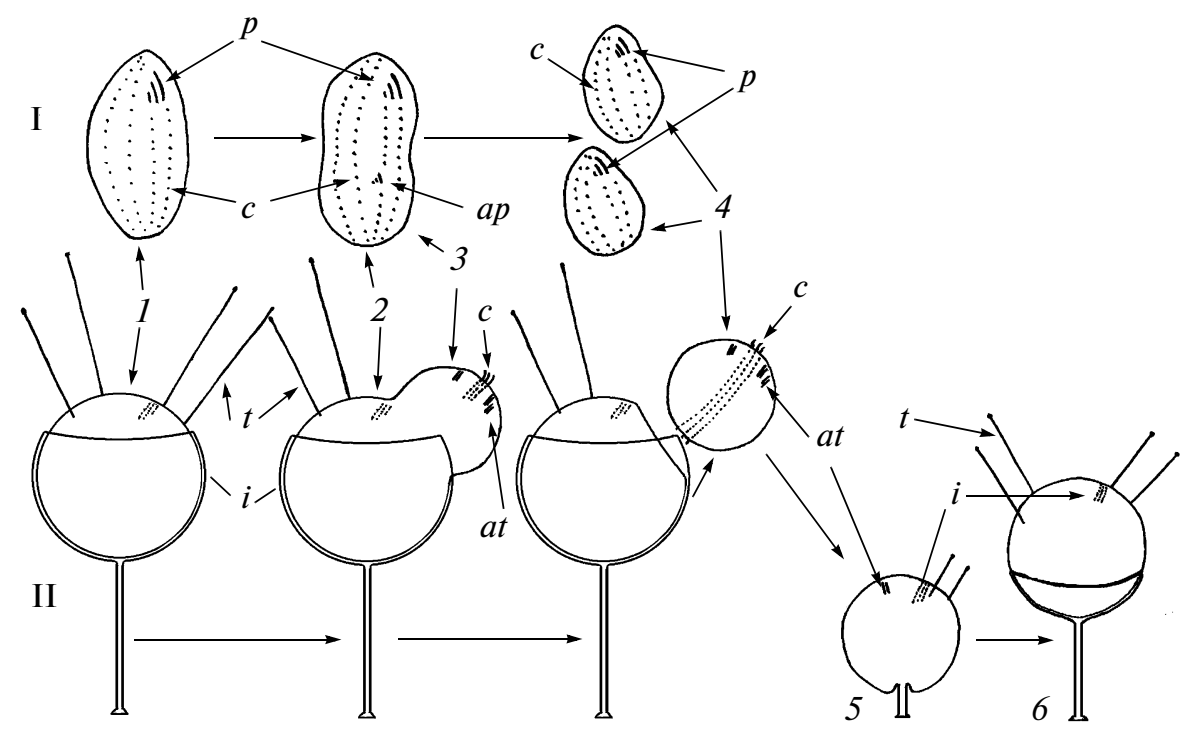

Fig. 2. Scheme of the ontogeny of mobile (I) (Jankowski, 1972, with changes) and sessile (II) (by example of suctorians) infusoria ontogenesis. (1) trophont; (2) tomont; (3) protomit; (4) tomit; (5-6) the swarmer metamorphosis; $c$ - ciliature; $i$-infraciliature; $a t$-anlage of the tentacle; $t$-tentacle; $p$-oral ciliatura; $a p$-anlage of the oral ciliatura (Dovgal, 2002a).

It should be mentioned that attempts to use the ontogenetic criteria for other groups of protists were less successful in spite of the fact that the well-known American protistologist Corliss supposed that there are some examples of recapitulations of ancestral features in many taxa of protozoa (Corliss, 1968). This is particularly related to the complicated, organized external structures, pellicula or different skeletal forms. According to Corliss these examples can be found in microsporidia (the spore wall structure), gregarines (gametocyte membrane), and coccidia and dinoflagellates (structure of the external skeleton).

In contrast to other protistologists, we assume that stomatogenesis of infusoria and early stages of metamorphosis of the settlement steps of sessile infusoria (and similar processes in other protists) cannot be explained by a biogenetic law and can be a demonstration of Baers' embryological resemblance law (Dovgal, 2000; Dovgal, 2002a). For ontogenesis of unicellular eukaryotes, a changed interpretation of this law was suggested (Dovgal, 2002a; Dovgal, 2008). The interpretation of the embryological resemblance law from the monograph of Schmalhausen (1969) was accepted as the base.

With regard to mechanisms of regulation of morphogenetic processes in protozoa, it is likely they are analogues or homologues found in multicellular animals. This indirectly testifies that the methods such as microsurgery, related to the transplantation of certain structures of the infusoria cortex, which are applicable for infusoria ontogenesis, are also useful for study of ontogenesis multicellular organisms (Beisson, 1994). Salts of lithium cause teratogenic effects in infusoria and in multicellular organisms (Beisson, 1994). This is also confirmed by tyrosine kinase receptors in choanoflagellates (King, Carroll, 2001; King et al., 2003).

The specificity of individual development of unicellular organisms appears in the regulatory role of cortical structures of the cell (Dovgal, 2002a). The cortex of multicellular organisms probably plays similar role only at early stages of ontogenesis for instance during ooplasmic segregation.

The processes of intercellular recognition in protists is raising some interest with regard to the evolutionary formation of the regulatory mechanism of morphogenesis during transition to multicellularity. First of all, these processes are related to reproduction in these organisms. However, there are some cases in which a few individuals from one species aggregate together to a single cell in protists, which reproduce only asexually (Fig. 3) or only connect to each other. Some infusorians spend the winter by grouping on the bottom of the water reservoir and creating large spherelike crowds, accumulating hundreds of thousands of species.

The problem of protozoa recognition has already been successfully studied by specialists in various groups of protozoa (Afon'kin, 1991). Similar processes have been under discussion as the models for studying morphogenesis mechanisms of multicellular organisms. One classical model of organisms is soilliving amoeba Dictyostelium discoideum Raper, in which the trophic phase of the life cycle is represented by single amoeba cells, reproducing by cell division. Some amoeboid individuals (in the center of the aggregation) upon exhaustion of food resources (bacteria) begin to synthesize and excrete into the environment a special substance (attractant) first called "acra- 


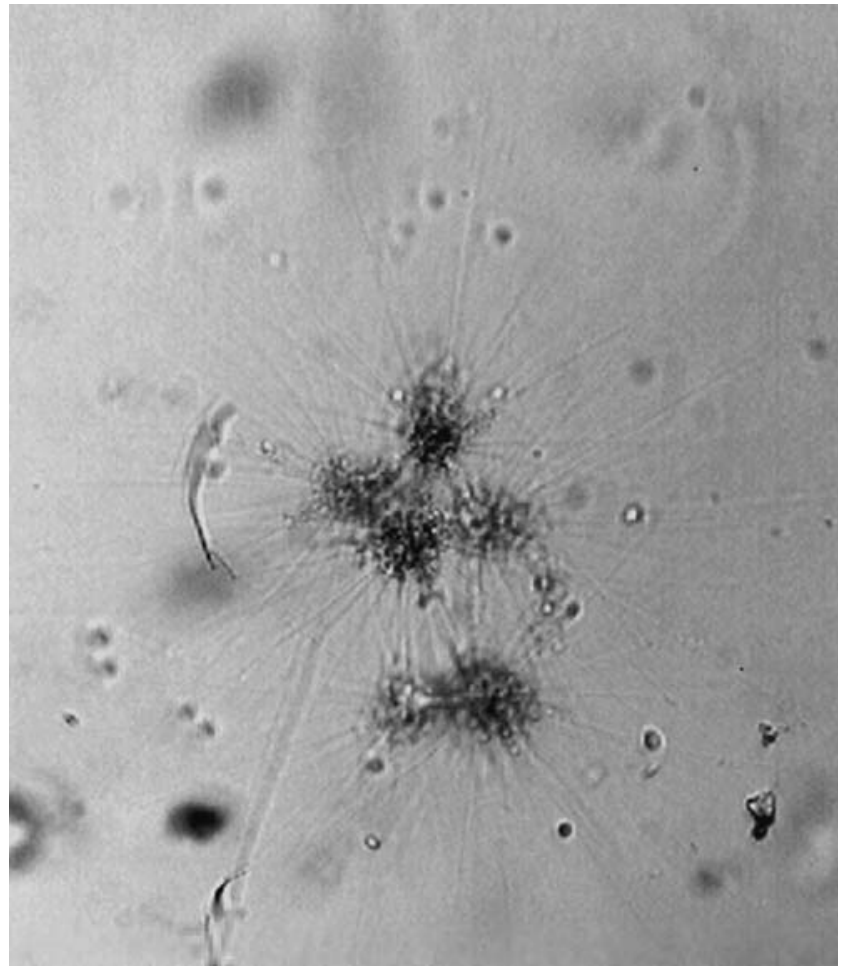

Fig. 3. Heliozoa aggregation. 320-fold enlargement.

sin," which stimulates other species to aggregate into groups around the aggregation center. Thus, pseudoplasmodium forms with further cell differentiation, which occur subsequently, provide for the rise of various parts of the carposome (or sorocarp) (Fig. 4). Some cells of the sorocarp differentiate to spores (Goldbeter, Segel, 1977; Novozhilov, Goodkov, 2000). It was determined later that the attractant is cAMP (cyclic adenosine monophosphate) and the process of its synthesis is autocatalytic. At the same time, the character of some amoeba movement looks like a concentric wave and there is the same analogue of cAMP functions with morphogenesis of multicellular animals as the carriers of information about the embryo. This resemblance, as well as the simplicity of verification, increased interest in mathematical modeling of the aggregation mechanism in $D$. discoideum as the nonequivalent process (Prigozin, Stengers, 2003; Litcanu, Velazquez, 2006).

Besides mechanisms based on excreting of aggregation or coupling pheromones into the environment by the cells, the mechanisms of intercellular recognition based on interaction between molecular membrane complexes provoke considerable interest (Afon'kin, 1991). This scheme particularly was developed for a single member of volvoxes, chlamidomonas (Musgrave, 1994), that allowed experimental testing of probable transition interactions between cells inside of colonies because the colonial volvoxes are the classical model objects for considering multicellularity. It should be mentioned that the hypothesis on the origin of multicellular organisms from colonial ancestors is probably the most experimentally verified due to studies of asexual reproduction of various species of volvoxes.

The first who paid attention to the resemblance between the formation of daughter colonies in volvox (Fig. 5) and the processes of blastulation and gastrulation in animals was Kuschakewitsch, a Kievian embryologist (Kuschakewitsch, 1923). Schmalhausen played a special role in publishing this research. Kuschakewitsch emigrated from the country in 1920 and his manuscript was finished and recommended by Schmalhausen for publication in the journal "Notes of the Physico-Mathematical Department" published by the Ukrainian Academy of Sciences. As a result, beginning from Kuschakewitsch's research and continuing until the present, the asexual reproduction of various species from the genus Volvox is a popular model of evolutionary development of morphogenetic processes during transition to multicellular organisms (Kirk, 2001, 2005; Kirk, Nishii, 2001; Desnitskiy, 2006; Michod, 2007; Herron, Michod, 2008). The members of few genera of volvoxes are usually placed in an evolutionary line beginning from members of the Chlamydomonas genus to spherical colonies of volvocines, which characterized with cell differentiation to "somatic" without the ability to reproduce and submerged in the colony gonidia, i.e., the cells producing new daughter colonies.

In spite of the fact that there are molecular data that volvocines are a young group about 70 million years old, these are a very comfortable model. However, even within this family, the transition from single forms to colonial with cell differentiation sometimes occurred independently (Kirk, 2005).

On the base of original data on the reproduction of volvoxes, Kirk (Kirk, 2001) supposed that three regulatory loci consequently appeared in the genome of volvoxes, which provided for the transition from unicellular organization to a function dividing between two particularized types of vegetative cells (somatic and gonidia). Kirk (Kirk, 2005) suggested a twelvestep model of transition to volvox colonies: the first step is noncomplete cytogenesis; steps 2 and 7 are inversion of the daughter colonies' cells; step 3 is the turn of basal bodies of the flagella, which is necessary for their contraction in one direction, providing the colony the ability to have forward movement; step 4 is polarity of colony creation (physiologically front and back ends); step 5 is creation of the extracellular matrix. The control of cell division in the colony appears on steps 6 and 8 , which are related to an increase in the extracellular matrix volume. The partial and then the total differentiation of functions between somatic cells and future gonidia occur on steps 9 and 10. The transition to asymmetric division occurs on step 11. In the final step, 12, the differenti- 


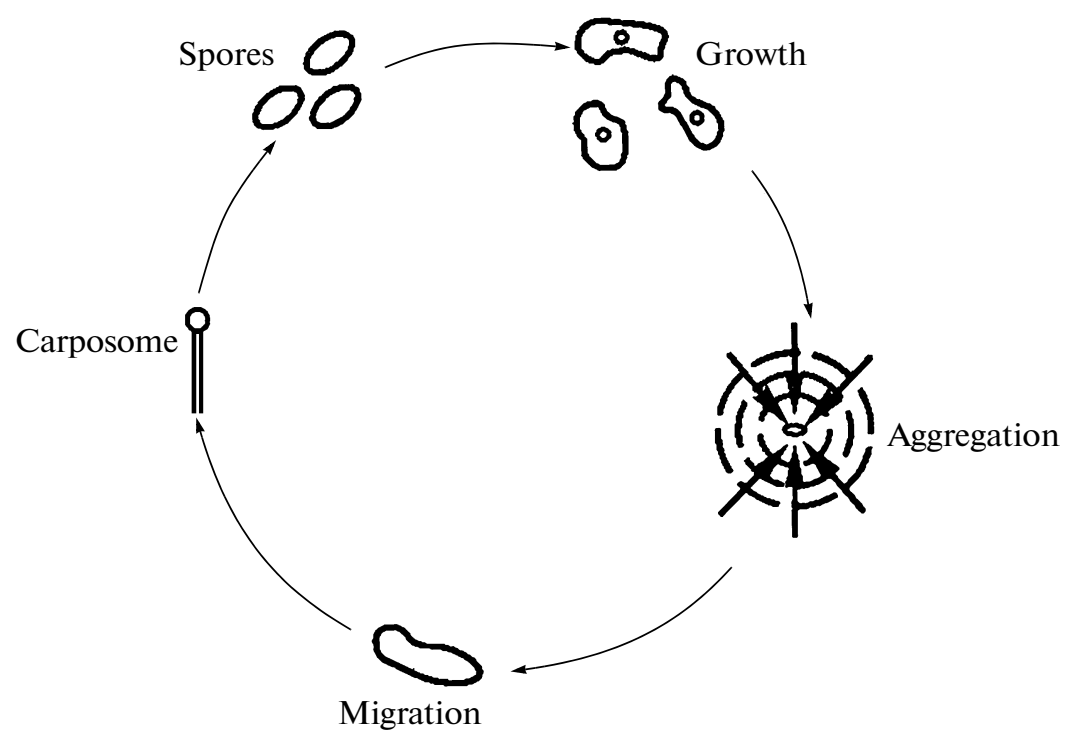

Fig. 4. Life-cycle of Dictyostelium discoideum [Prigozhin, Stengers, 2003].

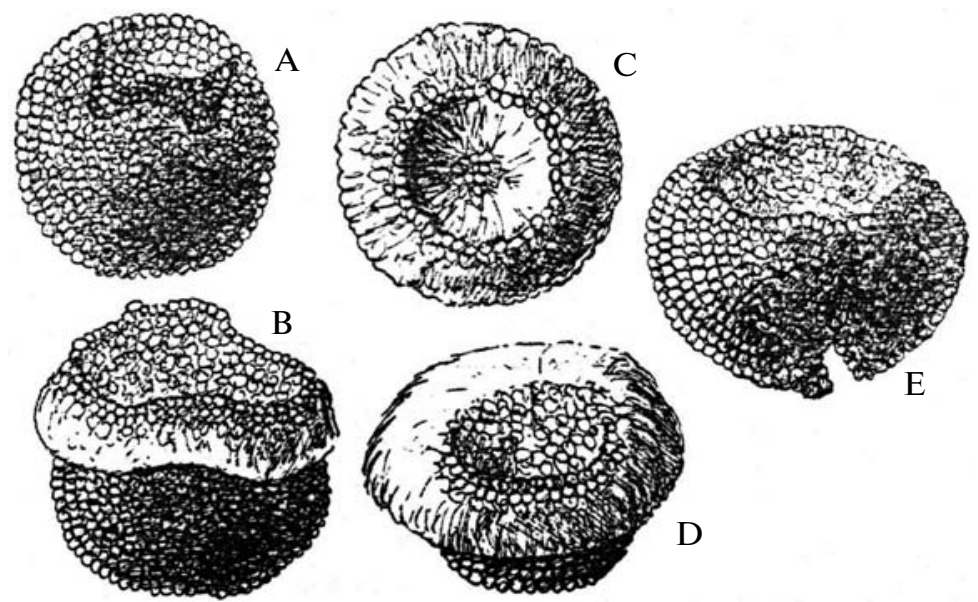

Fig. 5. Ontogenesis of Volvox colony (stage of “pseudogastrula”). A-protrusion of colony's surface; B, D (side view) and C (view from the mouth side) — wrench of sides; E (side view) — overcrossing of wrenched sides [Kuschakewitsch, 1923].

ation of the cell division program begins (bifurcation, according to Kirk).

On our opinion, this sequence of steps includes the stages when the regulation of the morphogenetic process occurs at the cell level (at steps 1-3) and also steps that require the mechanisms of intercellular interaction (steps 4-12).

There is the analogue with the Metazoa ontogenesis when at the first steps the regulatory mechanisms turn on in oospheres and then the intercellular mechanisms occur with the beginning of division.

Similar mechanisms appeared in unicellular eukaryotes, which provided the hypothetical ancestors of Metazoa with preliminary adaptation to multicellularity. Thus, the protozoa with a known sexual process were characterized with differentiation (including morphological) to vegetative and reproductive cells (gametes). In addition, there are communication systems between cells, creation of cell aggregates, recognition of complementary gametes according to their species, for instance pheromones involved in recognition of a victim, the pheromones of aggregation of noncolonial organisms, etc. (Afon'kin, 1991). Similar signal molecules or transmembrane proteins are also being produced by colonial protists (Gaidos et al., 2007).

This has also been shown by tyrosine kinase receptors in single choanoflagellates (King, Carrol, 2001; King et al., 2003), which in spite of this fact, as was already mentioned, led to the idea (Maldonado, 2004) that choanoflagellates are secondary simplified 
sponges and fungi were the ancestors of multicellular animals (Müller, 2003).

However, we supposed that the idea of the return of multicellular organisms to the unicellular level of organization leads to a break in the principle of evolution irreversibility. For instance, the extreme level of specialization to parasitism in myxosporea (phylum Myxozoa) did not lead to the total loss of multicellularity of organisms, because their spores and vegetative stages are multicellular (Pugachev, Podlipaev, 2007).

Therefore, more attractive is the version of secondary transition of some colonial choanoflagellates to single life, and single choanoflagellates kept tyrosine kinases which are necessary for morphogenesis of colonies of sessile choanoflagellates where, probably, primary cell differentiation occurred (Mikhailov et al., 2009). However, in the contrast to volvocines, choanoflagellates have no blastula-like stage. According to this, it was supposed that choano-ancestors of Metazoa, besides the sessile trophic colonial stage, had a settlement nonfeeding plankton stage of synzoospores, which is lost in modern choanoflagellates (Mikhailov et al., 2009).

On our opinion, the regulatory mechanisms of ontogenesis on the cell level in protozoa and also mechanisms of intercellular interaction between these organisms can serve not only as a model of mechanisms of creation of morphogenesis of multicellular organisms (like volvoxes) but also as mechanisms similar to those occurring in a fertilized ovum before mitosis.

Thus, according to the existing hypothesis on the appearance of the mentioned mechanisms at the cell level of structural organization, on our opinion, the evolutionary steps of formation of morphogenetic mechanisms for unicellular eukaryotes (according to Dovgal, 2008) and for Metazoa (according to Dondua, 2005b) can be combined in the following:

1. Complication of cell structure and differentiation of the locomotor and alimentary organelle. Complication of ontogenesis in parasitic and sessile forms due to the appearance of settlement (larval) stages. The sexual process provided by specialized gametes (gamete stage) or microconjugants is morphologically similar to the settlement stages.

2. Appearance of complicated cytostome and, thus, separation of physiologically front and back ends of the cell (axial organization). The appearance of cell mechanisms providing the differential activity of genes and morphological processes (such as stomatogenesis in infusoria).

3. The mechanism of appearance of intercellular recognition.

4. Transition to colonial structure.

5. Colony size enlargement that led to functional and morphological differentiation of species in a colony. The change of functions in intercellular recogni- tion mechanisms, which provide for the ontogenesis of colonies.

6. Cell differentiation of multicellular organisms and appearance of the mechanisms providing differential gene activity and various morphogenetic processes.

7. Complication of ontogenesis due to the appearance of settlement larval stages. Energetic capabilities of mature forms supplied the sexual process related to the formation of male and female gametes.

8. Formation of phagocytoblast and appearance of special gene systems, providing creation of axial organization in multicellular animals.

During the transition to multicellular organism structure, the cell regulatory mechanisms probably were partially lost and some of them providing the first steps of morphogenesis at the ovum stage were kept (Dovgal, 2002a; 2008).

It should be mentioned that the fifth and sixth steps of the evolutionary events described above are the range where the model objects for experimental proofs of the suggested hypothesis could be found and used later.

\section{REFERENCES}

Afon'kin, S.Yu., Cell-Cell Self-Recognition in Protozoa, in Itogi nauki i tekhniki. Ser. Zoologiya bespozvonochnykh. 9 (Advances in Science and Technology. Ser. Zoology of Invertebrates. 9), Moscow: VINITI, 1991, pp. 1-160 [in Russian].

Bauer, E.S., Teoreticheskaya biologiya (Theoretical Biology), Moscow: VIEM, 1935 [in Russian].

Beisson, J., Cytoskeleton and Molecular Basis of Pattering in Ciliates, in Proc. of the IX Intern. Congress of Protozool., Berlin, July 25-30, 1993, Hausmann, K. and Hulsmann, N., Eds., 1994, pp. 15-24.

Corliss, J.O., The Value of Ontogenetic Data in Reconstructing Protozoan Phylogenies, Trans. Amer. Micr. Soc., 1968, vol. 87, no. 1, pp. 1-20.

Desnitskiy, A.G., Evolutionary Reorganizations of Ontogenesis in Related Species of Coenobial Volvocine Algal, Ontogenez, 2006, vol. 37, no. 4, pp. 261-272.

Dogiel, V.A., Obshchaya protistologiya (General Protistology), Moscow: Sov. Nauka, 1951 [in Russian].

Dondua, A.K., Fundamentals of Comparative Embryology, in Biologiya razvitiya (Developmental Biology), St. Petersburg: S.-Peterb. Gos. Univ., 2005a, vol. 1 [in Russian].

Dondua, A.K., Cellular and Molecular Aspects of Ontogeny, in Biologiya razvitiya (Developmental Biology), St. Petersburg: S.-Peterb. Gos. Univ., 2005b, vol. 2.

Dovgal', I.V., Morphological and Ontogenetic Changes in Protozoa upon Transition to Sedentary Life, Zh. Obshch. Biol., 2000, vol. 61, no. 3, pp. 290-304.

Dovgal, I.V., The Germ Similarity in Ontogeny of Ciliates (Ciliophora), Vest. Zool., 2002a, vol. 36, no. 2, pp. 3-9.

Dovgal, I.V., Evolution, Phylogeny and Classification of Suctorea (Ciliophora), Protistology, 2002b, vol. 2, no. 4, pp. 194-270. 
Dovgal', I.V., Evolution of Ontogeny: from Protozoa to Metazoa, in Mater. Konf. "Sovremennye problemy biologicheskoi evolyutsii”, M., 17-20 sentyabrya 2007 g. (Proc. Conf. "Modern Problems of Biological Evolution," Moscow, Septemter 17-20, 2007), Moscow: Izd. GDM, 2007, pp. 34-35.

Dovgal', I.V., Evolution of Ontogeny and Emergence of Metazoa, in Tr. Konf. "Sovremennye problemy biologicheskoi evolyutsii". M., 17-20 sentyabrya 2007 g. ((Proc. Conf. "Modern Problems of Biological Evolution," Moscow, Septemter 17-20, 2007), Moscow: Izd. GDM, 2007, pp. 31-39.

Dovgal', I.V., Ontogeny of Unicellular Eukaryotes and Emergence of Metazoa, in Progr. i Tez. Dokl. Konf. "Nauchnoe nasledie Shmal'gauzena i ego razvitie”, M., 23-24 aprelya 2009 g. (Abstr. Conf. (Scientific Legacy of Schmalhausen, Moscow, April 23-24, 2009) 2009, pp. 16-17.

Eigner, P., Evolution of Morphogenetic Processes in the Orthoamphisiellidae N. Fam., Oxytrichidae, and Parakahliellidae N. Fam., and Their Depiction using a Computer Method (Ciliophora, Hypotrichida), J. Euc. Microbiol., 1997, vol. 44, no. 6, pp. 553-573.

Foissner, W., Ontogenesis in Ciliated Protozoa with Emphasis on Stomatogenesis, in Ciliates: Cells as Organisms, Hausmann, K., and Bradbury, P.C., Eds., Stuttgart: Gustav Fisher, 1996, pp. 95-177.

Frolov, Yu.P., Some Aspects of the Origin of Metazoa, Vestn. Samar. Univ., Estestvennonauchnaya Ser. 2006., vol. 47, no. 7, pp. 241-248.

Gaidos, E., Dubuc, T., Dunford, M., et al. The Precambrian Emergence of Animal Life: A Geobiological Perpective, Geobiology, 2007, vol. 5, no. 4, pp. 351-373.

Goldbeter, A. and Segel, L.A., Unified Mechanism for Relay and Oscillation of Cyclic AMP in Dictyostelium discoideum, Proc. Nat. Acad. Sci. USA, 1977, vol. 74, pp. 1543-1547.

Herron, M.D. and Michod, R.E., Evolution of Complexity in the Volvocinae Algae: Transitions in Individuality through Darwin's Eye, Evolution, 2008, vol. 62, no. 2, pp. 436-451.

Ivanov, A.V., Proiskhozhdenie mnogokletochnykh zhivotnykh. Filogeneticheskie ocherki (The Origin of Metazoa: Phylogenetic Essays), Leningrad: Nauka, 1968 [in Russian].

King, N. and Carroll, S.B., A Receptor Tyrosine Kinase from Choanoflagellates: Molecular Insights Into Early Animal Evolution, Proc. Nat. Acad. Sci. USA, 2001, vol. 98, no. 26, pp. 15032-15037.

King, N., Hittinger, C.T., and Carroll, S.B., Evolution of Key Signalling and Adhesion Protein Families Predates Animal Origins, Science, 2003, vol. 301, pp. 361-363.

Kirk, D.L. and Nishii, I., Volvox carteri As a Model for Studying the Genetic and Cytological Control of Morphogenesis, Develop. Growth Differ., 2001, vol. 43, pp. 621-631.

Kirk, D.L., A Twelve-Step Program for Evolving Multicellularity and a Division of Labor, BioEssays, 2005, vol. 27, pp. 299-310.
Kirk, D.L., Germ-Soma Differentiation in Volvox, Dev. Biol., 2001, vol. 238, pp. 213-223.

Kuschakewitsch, S.E., Zur Kenntnis der Entwicklungsgeschichte von Volvox, Zap. Fiz.-Mat. Viddilu, 1923, vol. 1, pp. 31-36.

Litcanu, G. and Velazquez, J.J.L., Singular Perturbation Analysis of CAMP Signalling in Dictyostelium discoideum Aggregates, J. Math. Biol., 2006, vol. 52, pp. 682-718.

Maldonado, M., Choanoflagellates, Choanocytes, and Animal Multicellularity, Inverteb. Biol, 2004, vol. 123, no. 1, pp. 1-22.

Michod, R.E., Evolution in Individuality During the Transition from Unicellular to Multicellular Life, Proc. Nat. Acad. Sci. USA, 2007, vol. 104, no. Suppl. 1, pp. 86138618.

Mikhailov, K.V., Konstantinova, A.V., Nikitin, M.A., et al., The Origin of Metazoa: A Transition from Temporal to Spatial Cell Differentiation, BioEssays, 2009, vol. 31, no. 7, pp. 758-768.

Müller, W.E.G., The Origin of Metazoan Complexity: Porifera As Integrated Animals, Integr. Comp. Biol., 2003, vol. 43, pp. 3-10.

Musgrave, A., Intracellular Signalling in Chlamydomonas, in Proc. of the IX Intern. Congress of Protozool., Berlin, July 25-31, 1993 Hausmann, K. and Hulsmann, N., Eds., 1994, pp. 53-54.

Novozhilov, Yu.K. and Goodkov, A.V., Class Eumycetozoea Zopf, 1884. Eumycetozoans (Slime Molds and Myxomycetes), in: Protisty: Rukovodstvo po zoologii. Ch. 1 (Protists: Handbook on Zoology, Pt. 1), Alimov, A.F., Ed., St. Petersburg: Nauka, 2000, pp. 417-444.

Prigozhin, I. and Stengers, I., Poryadok iz khaosa. Novyi dialog cheloveka s prirodoi (Order from Chaos: A New Dia$\log$ of the Man with Nature), Moscow: UPSS, 2003 [in Russian].

Pugachev, O.N. and Podlipaev, S.A., Phylum Mycozoa Grasse, 1970. In. Protisty: Rukovodstvo po zoologii. Ch. 2 (Protists: A Guide on Zoology, Pt. 2), Alimov, A.F., Ed., St. Petersburg: Nauka, 2007, pp. 1045-1082.

Seravin, L.N. and Goodkov, A.V., Amoeboid Properties of Cells during Early Morphogenesis and the Nature of a Possible Protozoan Ancestor of Metazoa, Zh. Obshch. Biol., 2005, vol. 66, no. 3, pp. 212-223.

Sewertzoff, A.N., Morfologicheskie zakonomernosti evolyutsionnogo protsessa, (Morphological Consistent Patterns of Evolution Processes) Sots. Rekonstruktsiya I Nauka, 1934, vol. 3, pp. 21-37.

Sewertzoff, A.N., Morfologicheskie zakonomernosti evolyutsii (Morphological Regularities of Evolution), Moscow: Akad. Nauk SSSR, 1939 [in Russian].

Shmal'gauzen, I.I., Problemy darvinizma (Problems of Darwinism), Leningrad: Nauka, 1969 [in Russian].

Tokin, B.P., The Problem of Cell Ontogeny. Communication 1: The Regeneration from the Point of View of Cell Ontogeny, Biol. Zh., 1934, vol. 3, no. 2, pp. 279-293.

Jankowski, A.W., Recapitulation of Phylogenesis in Ciliate Ontogeny, in Problemy evolyutsii (Problems of Evolution), Novosibirsk: Nauka, 1972, vol. 2, pp. 95-123. 